\title{
Basic knowledge of psychopathology does not undermine the efficacy of the Structured Inventory of Malingered Symptomatology (SIMS) to detect feigned psychosis
}

Citation for published version (APA):

Jelicic, M., Peters, M. J. V., Leckie, V., \& Merckelbach, H. L. G. J. (2007). Basic knowledge of psychopathology does not undermine the efficacy of the Structured Inventory of Malingered Symptomatology (SIMS) to detect feigned psychosis. Netherlands Journal of Psychology, 63(3), 107-110. https://doi.org/10.1007/BF03061071

Document status and date:

Published: 01/01/2007

DOI:

10.1007/BF03061071

Document Version:

Publisher's PDF, also known as Version of record

Please check the document version of this publication:

- A submitted manuscript is the version of the article upon submission and before peer-review. There can be important differences between the submitted version and the official published version of record. People interested in the research are advised to contact the author for the final version of the publication, or visit the DOI to the publisher's website.

- The final author version and the galley proof are versions of the publication after peer review.

- The final published version features the final layout of the paper including the volume, issue and page numbers.

Link to publication

\footnotetext{
General rights rights.

- You may freely distribute the URL identifying the publication in the public portal. please follow below link for the End User Agreement:

www.umlib.nl/taverne-license

Take down policy

If you believe that this document breaches copyright please contact us at:

repository@maastrichtuniversity.nl

providing details and we will investigate your claim.
}

Copyright and moral rights for the publications made accessible in the public portal are retained by the authors and/or other copyright owners and it is a condition of accessing publications that users recognise and abide by the legal requirements associated with these

- Users may download and print one copy of any publication from the public portal for the purpose of private study or research.

- You may not further distribute the material or use it for any profit-making activity or commercial gain

If the publication is distributed under the terms of Article 25fa of the Dutch Copyright Act, indicated by the "Taverne" license above, 


\section{Basic knowledge of psychopathology does not undermine the efficacy of the Structured Inventory of Malingered Symptomatology (SIMS) to detect feigned psychosis}

Marko Jelicic, Maarten J.V. Peters, Vanessa Leckie, and Harald Merckelbach

The aim of the present study was to examine whether basic knowledge of psychopathology undermines the efficacy of the Structured Inventory of Malingered Symptomatology (SIMS) to detect feigned psychosis. The SIMS was administered twice to participants without knowledge of psychopathology $(n=30)$ and participants with a basic knowledge of psychopathology $(n=31)$. On one occasion, they had to fill out the SIMS honestly. On the other occasion they were asked to complete the SIMS after they had been instructed to malinger psychosis because they were standing trial for a serious offence and wanted to avoid legal responsibility. Participants with knowledge of psychopathology engaged in less flagrant feigning on the SIMS than those without such knowledge. However, when asked to malinger psychosis, nearly all participants were classified by the SIMS as malingerers, regardless of their knowledge of psychopathology. It seems that a basic knowledge of psychopathology does not undermine the efficacy of the SIMS to detect feigned psychosis. (Netherlands Journal of Psychology 63, 107110.)

Keywords: Forensic psychology; malingering; feigning; assessment; psychosis; psychopathology

Especially when there is overwhelming evidence against them, defendants may decide to feign a mental disorder in an attempt to reduce their criminal responsibility (Ornish, 2001). While some defendants malinger memory impair-

Department of Clinical Psychological Science, Maastricht University

Correspondence to: Marko Jelicic, Department of Clinical Psychological Science, Maastricht University, PO Box 616, NL6200MD Maastricht,e-mail:m.jelicic@psychology. unimaas.nl

Submitted: 8 December 2006; revision accepted 13 June 2007. ments (Cercy, Schretlen \& Brandt, 1997) or posttraumatic stress disorders (Resnick, 1997b), others engage in feigning psychosis (Resnick, 1997a). An example of a well-known criminal who malingered psychosis is serial killer David Berkowitz, alias Son of Sam. He claimed that demons inhabiting a neighbour's dog ordered him to go and kill people. Three 'experts', two psychiatrists and one psychologist, declared Berkowitz psychotic and unfit to stand trial. Another psychiatrist disagreed and convinced the judge that the serial killer was feigning his psychotic episodes. Berkowitz later admitted 
that he had faked his psychosis in the hope of avoiding prison (Abrahamsen, 1985).

There is reason to believe that clinicians sometimes have considerable difficulty in detecting malingered psychosis. In a now classic study, Rosenhan (1973) had eight normal individuals admitted to psychiatric hospitals, all claiming they suffered from atypical auditory hallucinations. Although they stopped hearing voices once admitted to the hospital, all pseudopatients were diagnosed as schizophrenic and stayed in hospital for a considerable period of time. Procedures for diagnosing psychosis have improved since the early 1970 s when Rosenhan conducted his study (Spitzer, Lilienfeld \& Miller, 2005). However, the fact remains that many defendants have a strong motive to feign psychosis (cf. Ornish, 2001) and will do anything to make their malingering realistic. Rogers and Shuman (2000) therefore recommended that evaluations of criminal defendants should not rest solely on traditional interviews. They argued that other, additional, strategies to detect feigning should also be applied in forensic assessments. One such strategy is the use of special malinger tests.

A test specifically developed to detect feigned psychosis is the M-test, a 33-item self-report scale consisting of genuine and bogus symptoms of schizophrenia (Beaber, Marston, Michelli \& Mills, 1985). However, reviews have shown that this test has low hit rates (Rogers, Harrell \& Liff, 1993). Another and perhaps more promising instrument in this domain is the Structured Inventory of Malingered Symptomatology (SIMS; Smith, 1997; Smith \& Burger, 1997). The SIMS is a self-report measure designed to screen for malingered psychiatric symptoms and/or cognitive impairment. It consists of a range of items pertaining to feigning in five different areas, including psychosis. The idea behind the SIMS is that malingerers are unfamiliar with the way genuine symptoms manifest themselves. As a result, they may endorse atypical and bizarre symptoms that seem to be related to the condition they are feigning. Studies in which college students were instructed to simulate psychopathology or cognitive impairments have supported the usefulness of the SIMS for detecting feigning, with relatively high sensitivity and specificity rates (Edens, Otto, \& Dwyer, 1999; Merckelbach \& Smith, 2003; Rogers, Hinds, \& Sewell, 1996). Lewis, Simcox, and Berry (2002) showed that the SIMS also has diagnostic accuracy in defendants who underwent insanity evaluations. The SIMS has been translated into Dutch (Merckelbach, Koeyvoets, Cima \& Nijman, 2001) and German (Cima, Hollnack, Kremer, Knauer, SchellbachMatties, Klein \& Merckelbach, 2003). The Dutch and German versions of the SIMS also have acceptable psychometric properties.
Coaching, i.e., providing defendants with instructions on how to feign plausible symptoms, represents a real problem for the ability of experts to detect malingerers (e.g., Youngjohn, 1995). Accordingly, some authors have warned that malingerers with knowledge of psychiatric symptoms may feign mental disorders in a more sophisticated way than naive malingerers (Rogers, 1997). Jelicic, Hessels, and Merckelbach (2006) studied the effect of 'coaching' on the efficacy of the SIMS to detect feigned psychosis. Undergraduate students were asked to fill out the SIMS honestly or malinger psychosis imagining they were standing trial because of a serious offence. There were several groups of instructed malingerers. That is, some malingerers were provided with no further information, other malingerers received some information about psychotic symptoms, and still others were provided with information about psychosis and a warning not to exaggerate symptoms. However, even in the latter group, the group of coached malingerers, the SIMS had high diagnostic accuracy.

Although the SIMS appears to be relatively resistant to the effects of brief coaching, the possibility remains that knowledge of psychopathology may undermine the ability of the SIMS to detect feigned psychosis. In the present study, undergraduate students with and without basic knowledge of psychiatric symptoms were asked to fill out the SIMS twice. One of the times they had to fill out the questionnaire honestly, the other time they were instructed to simulate psychosis imagining they had to appear in court because they were charged with a violent crime and they wanted to avoid legal responsibility. We expected that, when asked to feign psychosis, most participants without knowledge of psychopathology would be classified by the SIMS as a malingerer. Furthermore, it was anticipated that a considerable proportion of participants with knowledge of psychiatric symptoms would be able to defeat the SIMS, i.e., when asked to malinger, they would be classified by the SIMS as an honest responder.

\section{Method}

\section{Participants}

The participants were 61 undergraduate students from Maastricht University. Some of them were psychology students, the others were studying health sciences or medicine. The group of participants without knowledge of psychopathology consisted of 30 undergraduates (two men) who had never taken a course on psychiatric disorders. Their mean age was $21.0(S D=2.5)$ years. The group of participants with basic knowledge of psychopathology comprised 31 undergraduates ( 2 men) who had taken at least 


\begin{tabular}{|c|c|c|c|}
\hline \multirow[t]{2}{*}{ Table 1} & \multicolumn{3}{|c|}{$\begin{array}{l}\text { Mean (SD) SIMS scores of the participants without knowledge of psychopathology }(n=30) \text { and } \\
\text { those with knowledge of psychopathology }(n=31) \text { when responding honestly and feigning } \\
\text { psychosis. }\end{array}$} \\
\hline & & Without knowledge of psychopathology & With knowledge of psychopathology \\
\hline \multicolumn{2}{|c|}{ Responding honestly } & $5.3(3.5)$ & $3.5(2.7)$ \\
\hline \multicolumn{2}{|c|}{ Feigning psychosis } & $45.9(14.2)$ & $37.0(12.8)$ \\
\hline
\end{tabular}

one course that exclusively focused on psychiatric disorders. Their mean age was $22.7(S D=$ 4.0) years. Participants received a small financial compensation $(€ 5)$. The study was approved by the standing ethical committee of the Faculty of Psychology (Maastricht University).

\section{Material}

A Dutch version of the SIMS (Merckelbach et al., 2001) was used. The SIMS is a self-report measure designed to screen for malingering in five different domains: low intelligence, affective disorders, neurological impairment, amnesia, and psychosis. It consists of 75 true-false items. As mentioned before, the items on the SIMS refer to bizarre and atypical symptoms. Typical items are 'There is nothing I can do, besides taking medication, that has any effect on the voices I hear' and 'People can put thoughts in my mind against my will'. To obtain a total score, yes-answers are summed. Total scores range from o to 75; a score exceeding the cut-off of 16 is considered to be indicative of malingering (Rogers et al., 1996).

\section{Procedure}

All participants were asked to fill out the SIMS twice: once honestly, the other time they were told to imagine they were standing trial for manslaughter and had decided to feign psychosis to avoid criminal responsibility. In both groups (without knowledge of psychopathology; with knowledge of psychopathology), half the participants were first asked to fill out the SIMS honestly, while the other half first had to malinger psychosis.

\section{Results}

The SIMS scores of the two groups are presented in table 1. When asked to fill out the SIMS honestly, participants without knowledge of psychopathology had significantly higher scores $[F(1,59)$ $=5.53, p<0.05]$ than participants with knowledge of psychopathology. Similarly, when asked to feign a psychosis, those without knowledge of psychopathology had higher scores $[F(1,59)=$ $6.52, p<0.02]$ than those with knowledge of psychopathology. Also, there was a borderline significant group (naive vs. knowledgeable) $\mathrm{x}$ instruction (responding honestly vs. malingering) interaction $[F(1,59)=3.96, p=0.05]$, meaning that the difference between participants with knowledge of psychopathology and those without such knowledge was particularly marked in the malinger condition. Nevertheless, when asked to fill out the questionnaire honestly, all participants (in both groups) had SIMS scores below the cut-off (16) for malingering (100\% specificity). When asked to feign psychosis, all of the participants without knowledge of psychopathology had SIMS scores exceeding the cut-off score for malingering (100\% sensitivity), while only one participant in the knowledgeable group had a score below this cut-off ( $97 \%$ sensitivity).

\section{Discussion}

The results of the present study can be summarised as follows. When asked to feign psychosis, participants with knowledge of psychopathology engaged in a somewhat less flagrant form of malingering on the SIMS than those without knowledge of psychopathology. However, knowledge of psychopathology hardly undermined the ability of the SIMS to detect feigned psychosis. When asked to malinger, all participants without knowledge of psychopathology and almost all with such knowledge were classified as malingerers. The present findings are in line with Jelicic et al. (2006) who found that providing brief coaching to malingerers on how to feign psychotic symptoms did not undermine the efficacy of the SIMS to detect feigned psychosis. Apparently, even people with basic knowledge of psychotic symptoms are unable to mimic the features of psychosis in such a way that they can defeat the SIMS.

It should be noted that in the present study the participants with knowledge of psychopathology only had some basic knowledge of psychotic symptoms. Although these participants had taken at least one course on psychopathology, they were by no means experts in the field of clinical psychiatry. It is conceivable that people with a certain expertise in psychopathology, for example psychiatric nurses or residents in 
psychiatry, are better able to defeat the SIMS. Future research could focus on the efficacy of the SIMS to detect feigned psychosis in people with expert knowledge of psychopathology. Nonetheless, the present findings suggest that malinger- ers who try to prepare themselves for a forensic evaluation by reading a textbook or consulting the Internet will have difficulty in defeating the SIMS. Our findings indicate that the SIMS is a valuable tool in forensic assessments.

\section{References}

Abrahamsen, D. (1985). Confessions of the Son of Sam. New York: Columbia University Press.

Beaber, R.J., Marston, A., Michelli, J \& Mills, M.J. (1985). A brief tests for measuring malingering in schizophrenic individuals. American Journal of Psychiatry, 142, 1478-1481.

Cima, M., Hollnack, S., Kremer, K., Knauer, E., Schellbach-Matties, R., Klein, B. \& Merckelbach, H. (2003). Strukturierter Fragebogen Simulierter Symptome: Die Deutsche Version des "Structured Inventory of Malingered Symptomatology: SIMS”. Nervenarzt, 11, 977-986.

Cercy, S.P., Schretlen, D. J. \& Brandt, J. (1997). Simulated amnesia and the pseudo-memory phenomena. In: R. Rogers (Ed.), Clinical assessment of malingering and deception, second edition (pp. 85-107). New York: Guilford Press.

Edens, J.F., Otto, R. K. \& Dwyer, T. (1999). Utility of the Structured Inventory of Malingered Symptomatology in identifying persons motivated to malinger psychopathology. Journal of the American Academy of Psychiatry and the Law, 27, 387-396.

Jelicic, M., Hessels, A. \& Merckelbach, H. (2006). Detection of feigned psychosis with the Structured Inventory of Malingered Symptomatology (SIMS): A study of coached and uncoached simulators. Journal of Psychopathology and Behavioral Assessment, 28, 19-22.

Lewis, J. L., Simcox, A.M. \& Berry, D.T. R. (2002). Screening for feigned psychiatric symptoms in a forensic sample by using the MMPI-2 and the Structured Inventory of Malingered Symptomatology. Psychological Assessment, 14, 170-176.

Merckelbach, H., Koeyvoets, N., Cima, M. \& Nijman, H. (2001). De Nederlandse versie van de SIMS. De Psycholoog, 36, 586-591.

Merckelbach, H. \& Smith, G.P. (2003). Diagnostic accuracy of the Structured Inventory of Malingered Symptomatology (SIMS) in detecting malingering. Archives of Clinical Neuropsychology, 18, 145-152.

Ornish, S.A. (2001). A blizzard of lies: Bogus psychiatric defenses. American Journal of Forensic Psychiatry, 22, 19-30.
Resnick, P.J. (1997a). Malingered psychosis. In: R. Rogers (Ed.), Clinical assessment of malingering and deception, second edition (pp. 47-67). New York: Guilford Press.

Resnick, P.J. (1997b). Malingering of posttraumatic disorders. In: R. Rogers (Ed.), Clinical assessment of malingering and deception, second edition (pp.130152). New York: Guilford Press.

Rogers, R. (1997). Current status of clinical methods. In: R. Rogers (Ed.), Clinical assessment of malingering and deception, second edition (pp. 373-397). New York: Guilford Press.

Rogers, R., Harrell, E.H. \& Liff, C.D. (1993). Feigning neuropsychological impairment: A critical review of methodological and clinical considerations. Clinical Psychology Review, 13, 255-274.

Rogers, R., Hinds, J.D. \& Sewell, K.W. (1996). Feigning psychopathology among adolescent offenders: Validation of the SIRS, MMPI-A, and the SIMS. Journal of Personality Assessment, 67, 244-257. Rogers, R. \& Shumann, D.W. (2000). Conducting insanity evaluations, second edition. New York: Guilford Press.

Rosenhan, D. (1973). On being sane in insane places. Science, 172, 250-258.

Smith, G.P. (1997). Assessment of malingering with self-report instruments. In: R. Rogers (Ed.), Clinical assessment of malingering and deception, second edition (pp. 351-370). New York: Guilford Press.

Smith, G.P. \& Burger, G.K.(1997). Detection of malingering: Validation of the Structured Inventory of Malingered Symptomatology. Journal of the American Academy of Psychiatry and the Law, 25, 183189.

Spitzer, R.L., Lilienfeld, S.O. \& Miller, M.B. (2005). Rosenhan revisited: The scientific credibility of Lauren Slater's pseudopatient diagnosis study. Journal of Nervous and Mental Disease, 193, 734-738. Youngjohn, J. R. (1995). Confirmed attorney coaching prior to neuropsychological evaluation. Assessment, 2, 279-283. 